\title{
An invasive gull displaces native waterbirds to breeding habitats more exposed to native predators
}

\author{
Piotr Skórka · Rafał Martyka · Joanna D. Wójcik • \\ Magdalena Lenda
}

Received: 26 May 2013/Accepted: 27 December 2013/Published online: 1 February 2014

(C) The Author(s) 2014. This article is published with open access at Springerlink.com

\begin{abstract}
The effect of invasive opportunistic predators may include population changes in both native prey and native predators as well as alteration of predator-prey interactions. We analyzed the activity of native magpie Pica pica and changes in population, nest sites and nesting success probability of native waterbirds (namely: grebes, ducks, rails and native gulls) in response to the population growth of the invasive Caspian gull Larus cachinnans. The study was carried out at a reservoir in southern Poland and at a similar control reservoir where the Caspian gull was absent. Both the invasive gulls and the native magpie are opportunistic predators of nests of native waterbirds. The population increase of the invasive gull led to a decline in the population of native black-headed gulls Larus ridibundus only. However, the invasive gull displaced all the native species from the breeding islets located in the central part of the reservoir to islets located close to the shoreline. The latter were frequently visited by magpies, which depredated on nests along the shores, leading to an up to threefold decrease in nesting success as compared
\end{abstract}

Electronic supplementary material The online version of this article (doi:10.1007/s10144-013-0429-7) contains supplementary material, which is available to authorized users.

P. Skórka $(\bowtie)$

Institute of Zoology, Poznan University of Life Sciences,

Wojska Polskiego 71C, 60-625 Poznań, Poland

e-mail: skorasp@poczta.onet.pl; skorasp@gmail.com

R. Martyka · M. Lenda

Institute of Nature Conservation, Polish Academy of Sciences, Mickiewicza 33, 31-120 Kraków, Poland

J. D. Wójcik

Institute of Systematics and Evolution of Animals, Polish

Academy of Sciences, Sławkowska 17, 31-016 Kraków, Poland with nests located in the central area of the invaded reservoir. Predation by Caspian gulls was rarely observed. Thus, the invasion of Caspian gull caused complex direct and indirect effects on the waterbird community that included competition for breeding sites, changes in the spatial distribution of nests and alteration of predation rate by native predators. Moreover, the effects of invasion may not be reflected by changes in population size of native species.

Keywords Alien species - Competition - Expansion · Habitat choice · Predation

\section{Introduction}

Invasive species can profoundly affect native ecosystems because they interact with native species in many ways and at different spatial and temporal scales (Vitousek et al. 1997; Wilcove et al. 1998; Mooney and Cleland 2001; $\mathrm{McGeoch}$ et al. 2010). Invasive species may change the structure of native habitats (Farrer and Goldberg 2009), alter interactions between native species (Bompard et al. 2013) or outcompete them (Evans and Toler 2007). However, the strongest effect on native species may occur when the invasive species are predators (Mooney and Cleland 2001; Finney et al. 2003; Bonnaud et al. 2009). In general, even one predatory species may affect the structure of entire species assemblages via consumption of prey from lower trophic levels, thus predation is a top-down force and may have stabilizing effects on ecosystems (Paine 1966; Schmitz 1998). Moreover, predators may indirectly affect the spatial distribution of prey species that are reluctant to settle or move in areas with high predation risk (Schmitz et al. 1997; Turner and Montgomery 2003). Invasive alien 
predators may elicit similar effects on native species assemblages (Hollebone and Hay 2008). Moreover, as most invasive alien predators are opportunistic, reach high abundances and lack a long co-evolutionary history with native prey, their impact on native species assemblages is usually much stronger than that of native predators (Finke and Snyder 2010; Hogg and Daane 2011). Recent metaanalyses indicate that the effect of invasive predators on prey abundance is usually twice as strong as that exerted by native predatory species (Salo et al. 2007; Paolucci et al. 2013).

Invasive predators interact not only with native prey but also with native predators. Thus, intra-guild interactions in a predator community may emerge and this may have profound effects on both predators and native prey communities (Snyder and Evans 2006; Hogg and Daane 2011). Invasive predators may displace native predators either directly, via intra-guild predation, or indirectly, through scramble competition (Pope et al. 2008; Cupples et al. 2011; Hogg and Daane 2011). Therefore, the negative impact of invasive predatory species may spread beyond the native predators to indirectly affect native prey as well (Gregory and Quijón 2011; Hogg and Daane 2011). However, an understanding of the influence of predatory invaders on native prey in areas of increasing overlap with their native predatory counterparts remains elusive. Theoretically, to coexist, competing species must use resources differently and have differing competitive abilities, which leads to niche partitioning (Hardin 1960; Abrams 1983, 2000). Native predators may utilize different food sources, habitats, or activity times to avoid competition from, and/or predation by the invasive predatory species (Kiesecker and Blaustein 1997; Abrams 2000; Relyea 2003; Forstmeier and Weiss 2004; Morosinotto et al. 2010).

Among birds, a large number of species suffer from the invasion of alien animals (McGeoch et al. 2010; Rands et al. 2010; Brzeziński et al. 2012). However, this negative impact is habitat dependent; oceanic islands, native grassland and forests seem to be the most affected (Wiles et al. 2003; Flanders et al. 2006; Bonnaud et al. 2009; Elliott et al. 2010; Pons et al. 2010; Strubbe et al. 2010). One habitat that is often invaded by alien species, primarily plants and invertebrates, is inland wetlands (for example: lakes, ponds and river beds). Worldwide, wetlands are an endangered habitat (Rahel and Olden 2008; Keddy et al. 2009; Sutherland et al. 2012). The human-related destruction of these habitats and rising global temperatures have become the principal contributors to the loss of fifty per cent of all the world's wetlands since 1900 (Finlayson and Davidson 1999). Similarly, partially as a consequence of habitat loss, the global waterbird population has decreased by $44 \%$ in the few past years alone (Delany et al. 2010) and numerous studies have reported notable declines in waterbirds on a local scale (Crowe et al. 2008; Ma et al. 2009; Sandilyan et al. 2010). However, very little is known about the part played by invasive species in this decline, with the exception of the well-documented role of predatory alien mammals such as, for instance, the American mink Neovison vison (Nordström et al. 2002; Brzeziński et al. 2012) or the raccoon Procyon lotor (Ellis et al. 2007).

One invasive species, which has colonized wetlands in Central Europe, is the Caspian gull Larus cachinnans. The native range of this species extends eastwards from the Black Sea, through the steppe zones, to Eastern Kazakhstan (Malling Olsen and Larsson 2004). Its population has grown rapidly and expanded both north and west, mainly along large river valleys into the interior of the European continent (Filchagov 1996; Jonsson 1998; Lenda et al. 2010). The first breeding pairs in Poland were recorded in the Middle Vistula valley in the late 1980s, with inland reservoirs in Southern Poland being colonized a few years later (Faber et al. 2001; Skórka et al. 2005). The Caspian gull is a large (56-68 cm long, with a $140-150 \mathrm{~cm}$ wingspan and a body mass of 700-1,600 g) colonial waterbird (Malling Olsen and Larsson 2004). Its colonies consist of up to several thousand breeding pairs along the coast or on marine islands and several hundred breeding pairs on inland water reservoirs. During the breeding season, which lasts from the end of March to the beginning of June at inland reservoirs, the colonies are located predominantly on either islets or shores (Skórka et al. 2005; Lenda et al. 2010). The availability of islets is a factor that limits the local population sizes of many waterbirds (Amat 1985; Skórka et al. 2006; Kajzer et al. 2012). When the islets are overtaken by invasive species, this may lead to population declines in the native species. The decline may be even stronger given that, like many other large gulls, the Caspian gull is an opportunistic predator that steals waterbirds' eggs and hunts their chicks (Vidal et al. 1998; Bosch et al. 2000; Väänänen 2000; Hernandez-Matias and Ruiz 2003). This predatory behaviour may thus act in synergy with competition for nesting sites to increase the negative effect of this invasive species.

Following the definition of an invasive species provided by Rahel and Olden (2008) we consider the population explosion and spread of Caspian gull as an invasion (Lenda et al. 2010). Because the Caspian gull is primarily a seabird that breeds on coastal islands in its native geographical range, it is alien to inland waterbodies. The main reasons underlying this extensive expansion were vast manmade alterations in the environment that facilitated both high reproductive success and their spread into the interior of the continent (Fasola et al. 1993; Jonsson 1998; Skórka et al. 2005; Lenda et al. 2010). This species utilizes humanrelated food resources in newly colonized areas, mostly fish farms and refuse tips (Lenda et al. 2010). Moreover, new 
breeding colonies and their persistence is dependent on these anthropogenic food resources (Lenda et al. 2010). The Caspian gull has also huge potential impact on native ecosystems because it is a large-bodied predator that hunts fish and other waterbirds. Its population has been growing rapidly and this may also introduce economic costs as this species may cause loss in fish production on fish farms and spread pathogens (Gwiazda 2004; Skórka et al. 2009).

However, the Caspian gull is not the sole predator that is capable of exploiting native waterbird populations. At inland reservoirs, there are native opportunistic predators, the best-known are corvids: the magpie Pica pica and the carrion crow Corvus cornix (Montevecchi 1976; Bukaciński and Bukacińska 2000; Zduniak 2006). They often depredate the eggs and chicks of ducks and gulls. Yet, there are surprisingly few studies of the effect of corvid predation on the breeding success of waterbirds (Ewins 1991; Stien et al. 2010). Corvids usually operate at the shores and edges of breeding colonies and may take up to twenty per cent of eggs in individual waterbird colonies (Montevecchi 1976, 1977; Burger 1984a). When predating on eggs, corvids usually take eggs away from the nest to consume them in safety because nest owners chase intruders away (Montevecchi 1976). Corvids such as magpies are relatively slow fliers; thus they operate mostly on unattended nests located at the edges of waterbird colonies or close to shoreline (Montevecchi 1976). The red fox Vulpes vulpes is another native predator of European waterbirds, primarily colonial ones. However, its activity is also concentrated on shores and its impact is dramatic only when it occasionally reaches the colonies located on islands (Erwin et al. 2001; Ruiz-Olmo et al. 2003).

The differing colonization of inland reservoirs by Caspian gull may be regarded as a natural experiment as it creates an exceptional opportunity to study the effects of gull invasion on native species. Using two similar sites, one invaded by Caspian gulls and the other not, we examined how an increasing gull population affects the abundance and behaviour of native predators (namely, magpie), the populations of native waterbirds, the spatial distribution of their nest sites and probability that nests survive to hatching. Then, we inferred the relative impact of invasive and native predators on the structure of native waterbird community. Specifically, we hypothesized that:

(1) The activity of native predators (corvids, foxes) will be concentrated mostly on shores and they will predate on the nests of waterbirds built on islets near the shore both at the invaded and control reservoirs;

(2) The increase in Caspian gull population will lead to the decrease in the number of native waterbirds at the invaded reservoir but not at the control one. We expect this decrease derives from two processes: predation and competition for nesting islets. We assume there will be a strong negative impact of this gull on native species as predation success and competitive abilities are directly linked to body size (Lindstrom 1988; Jonart et al. 2007; Oro et al. 2009; Schröder et al. 2009) and the Caspian gull is much larger than most of the native waterbirds which are potential prey and competitors;

(3) Assuming that the large body size of Caspian gull does correspond with its competitive ability, this species will also displace native waterbirds from safe islets located in the center of the reservoir to suboptimal islets located near the shore (i.e., exposed to the predatory activity of native corvids);

(4) The increasing population of Caspian gull will lead to increased nest predation on islets visited by this gulls and consequently lower nesting success of native waterbirds at the invaded reservoir as compared with the control one;

(5) Over time, the invasion of the Caspian gull will lead to a decline in the population size of small-bodied native predators, namely corvids, as an effect of scramble competition.

\section{Methods}

\section{Study area}

The study was carried out between 1996 and 2003 at two water reservoirs near the town of Tarnów, Southern Poland (Fig. 1). The first covers 20 ha and was colonized by Caspian gull in 1992. The second, with an area of 12 ha, is located $1 \mathrm{~km}$ to the south of the first (Fig. 1). The Caspian gull was not present there, so it served as the control reservoir and is referred to as such throughout this paper. Both reservoirs had a similar rectangular shape, were within $500 \mathrm{~m}$ from the Biała and Dunajec rivers and were situated in a suburban agricultural landscape (Fig. 1). The first had 86 islets, which were nesting sites for waterbirds, while the control reservoir had 40 islets. The size of islets varied from 1 to $50 \mathrm{~m}^{2}$, with the exception of one larger islet measuring 1 ha, located at the reservoir invaded by the Caspian gull. Vegetation was scarce on the islets and at the shores, which were predominantly covered in feather reed grass Calamgrostis epigejos and stinging nettle Urtica dioica at both reservoirs.

Monitoring the populations and activity of native predators and activity of invasive Caspian gulls

Between 1996 and 2001 at the invaded reservoir and between 1997 and 2003 (excluding 2002) at the control 


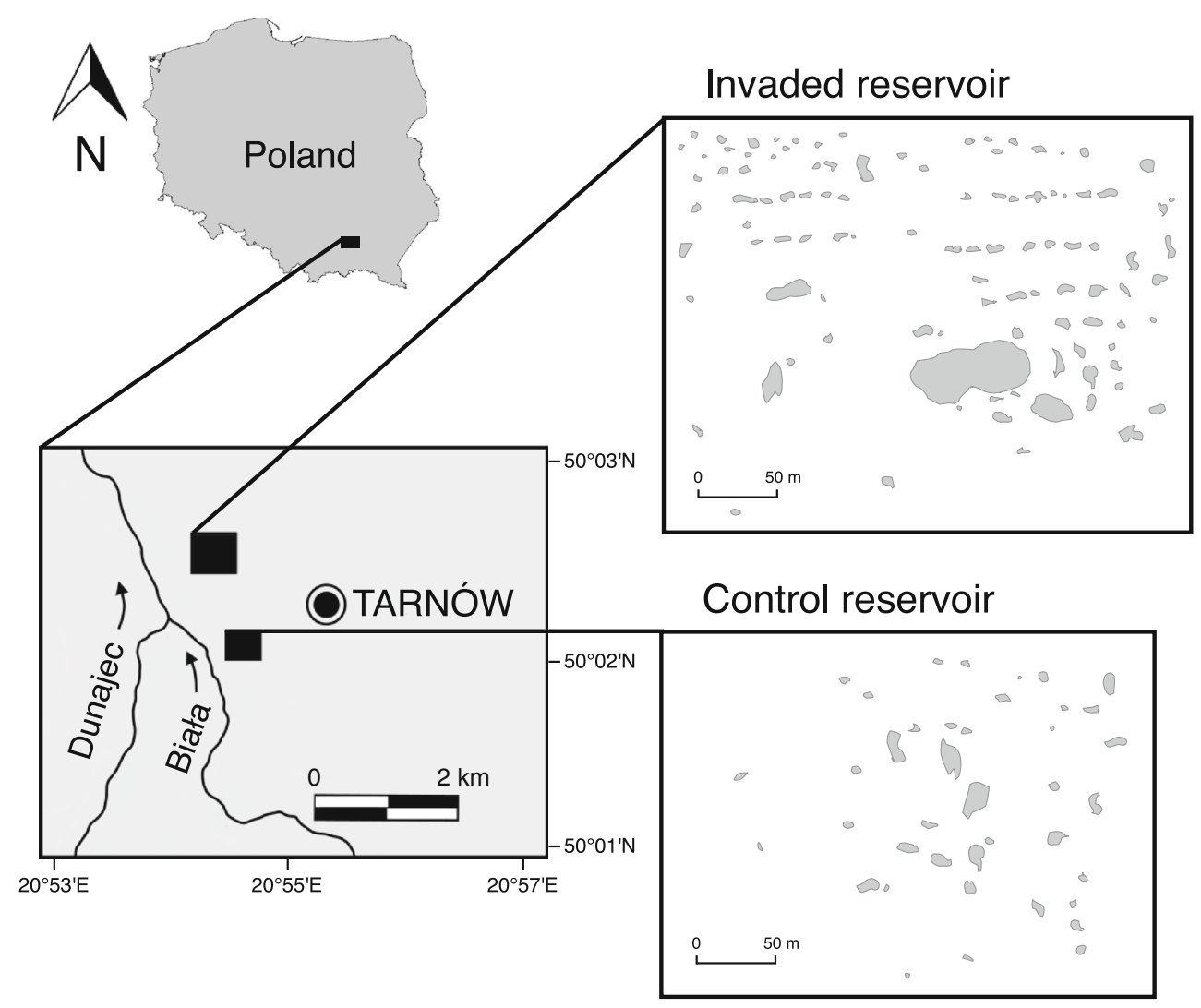

Fig. 1 Map of the study area. The shaded areas indicate the islets

reservoir, we counted all the corvid nests, namely magpie and carrion crow, on the shores of both reservoirs, as well as foxes' dens. The width of the shore varied between 20 and $30 \mathrm{~m}$ and was easily delineated by dirt roads around both reservoirs separating them from other habitats. As the visitation rate of predators is correlated with the probability of nest loses (e.g., Kuehl and Clark 2002; Lima 2009; see also "Results") we estimated the predator visitation frequency on islets. To establish the frequency of visits of magpies and carrion crow on the islets, we conducted observations of corvid visits during each year of the study. The observations were carried out from elevated sites along the shores to ensure visual coverage of every part of the reservoir. We spent between 100 and $150 \mathrm{~h}$ (mean \pm SEM $=3.8 \pm 0.9 \mathrm{~h}$ per observation day; range $2-8 \mathrm{~h}$ ) noting the visitation numbers each year and recording the islets concerned. Observations usually started between 8 a.m. and 11 a.m. when the foraging activity of corvids is the highest (Stouffer and Caccamise 1991) and the duration and frequency of observations did not vary between years at either reservoir. In the case of the Caspian gull, the rate of visitation events was gathered only for islets where that species was absent as a breeder, during observations of corvid visits on the islets. On islets with Caspian gull nests, we assumed its constant presence.
Monitoring the population sizes and nest distribution of native waterbirds and invasive Caspian gulls

We monitored the size of breeding populations of native waterbirds at the reservoir invaded by Caspian gull between 1996 and 2001. As in the case of predators (above) we used the number of nests as the estimate of population size. The monitoring of some species was halted after 2001 at this reservoir because it was flooded and $80 \%$ of the islets disappeared. The monitoring of waterbird population sizes at the control reservoir was conducted between 1997 and 2003, excluding 2002, when no nest counts were conducted apart from the black-headed gull nests.

We counted the nests of the native waterbirds breeding at reservoirs, namely ducks (mallard Anas platyrhynchos, common pochard Aythya ferina and tufted duck Aythya fuligula), grebes (little grebe Tachybaptus rufficolis and black-necked grebe Podiceps nigricollis), rails (Eurasian coot Fulica atra and common moorhen Gallinula chloropus), common gull Larus canus and black-headed gull Larus ridibundus between the beginning of April and the middle of June each year.

The population size of the invasive Caspian gull was monitored by the same methods and was the subject of a more detailed population study (Skórka et al. 2005, 2012). 
We collected data on the number of breeding Caspian gulls since 1992 (when the species first colonized the reservoir).

All nests of waterbirds and invasive Caspian gulls were plotted on detailed maps. We measured size $\left(\mathrm{m}^{2}\right)$, distance to shore $(\mathrm{m})$ and vegetation height $(\mathrm{cm})$ of islets at both the invaded and control reservoirs. The distance to the shoreline did not correlate with either the islet size (bootstrapped correlation coefficient, $r=0.120, P=0.271, n=86$ ) or the vegetation height $(r=-0.059, P=0.589, n=86)$, nor did the latter two variables correlate with each other ( $r=0.152, P=0.162, n=86$ ) at the invaded reservoir. The distance to the shoreline did not correlate with either the islet size ( $r=0.229, P=0.155, n=40)$ or the vegetation height ( $r=0.182, P=0.261, n=40$ ), nor did the latter two variables correlate with each other $(r=0.099$, $P=0.543, n=40$ ) at the control reservoir.

\section{Determining nesting success}

We conducted regular checks of selected nests of native waterbirds and Caspian gulls at intervals of around 5 days (except in 1999-2001 that were done every 3 days) to establish nest histories and nesting success probability (in other words, whether the chicks hatched or if the nest was depredated). During the surveys, we counted eggs and marked each with an individual code with permanent nontoxic marker. We noted all the cases where the eggs had been depredated or had disappeared and recorded the hatching of chicks. If at least one chick hatched we considered the nest to have had a nesting success.

The only nest failures other than predation were caused by nest abandonment and when eggs rolled out of the nests because of territorial disputes. Almost all instances occurred in the black-headed gull (Skórka et al. 2012) and only two cases were noted in mallard and common gull but they were not included in the analysis. Flooding was never observed at either of the studied reservoirs during the nesting period.

\section{Data analysis and statistics}

A generalized linear mixed model (GLMM) with logit link function, implemented in the SPSSv20 (IBM Corp Released 2011) software, was used to test how the islet features, namely distance to the shoreline, size and vegetation height, and the presence of Caspian gulls affected magpie visitation events at the invaded and control reservoirs. The presence of Caspian gulls was not tested at the control reservoir, as this species was not recorded there. Magpie visitations were coded as a binary response variable, with 0 indicating no observation of magpie on a given islet and 1 indicating that magpies were observed at a given island between 1996 and 2001 at the invaded reservoirs and between 1997 and 2003 at the control reservoirs. In the case of Caspian gull, the islets were classified in three categories, with 0 for no visit observed, 1 for at least one visit noted and 2 for an islet with one or more breeding pairs of Caspian gull. The year and identity of the islet were used as random factors in the analysis.

To test if the number of nests of breeding waterbirds was negatively correlated with the number of Caspian gulls and magpies we used a bootstrapped coefficient of correlation; 1,000 bootstraps, performed in RundomPro 3.14 (Jadwiszczak 2009). This method is recommended when sample sizes are small and the data distributions unknown (Flachaire 1999). We also used this correlation analysis to detect temporal changes (positive or negative) in the number of native waterbirds, corvids and invasive Caspian gull and to test correlations between environmental variables. In addition, we calculated the mean rate of population growth for each species or species group at the invaded and control reservoirs. The population growth rate $R$ was calculated as $R=N_{t+1} / N_{t}$, where $N$ is number of breeding pairs in year $t$ and in next year $t+1$. The mean rate of population growth for each species or species group was compared with bootstrapped $t$ tests (implemented in RundomPro 3.14 software) between the invaded and control reservoirs.

To test if the spatial distribution of the nests of all the native waterbirds changed and number of nests on islets near the shore increased we used the bootstrapped correlation analysis (see above). We classified all islets in both reservoirs into (1) those located near the shore and (2) those located in the central part of the reservoirs and classified nests accordingly. Islets located near the shore were defined as those up to $50 \mathrm{~m}$ from the shoreline. This division was made on the frequency of magpie visits. At the invaded reservoir, 85 of 129 (66\%) visits were within $50 \mathrm{~m}$ from the shoreline. At the control reservoir, 35 of 67 (55\%) visits were within $50 \mathrm{~m}$ from the shoreline. In total, 47 of $86(55 \%)$ islets at the invaded reservoir and 20 out of $40(50 \%)$ islets at the control reservoir were classified as close to the shore and the proportion of these islets did not differ between the two reservoirs $\left(\chi^{2}=0.237, d f=1\right.$, $P=0.626)$.

To assess whether the nesting success of native waterbirds was dependent on magpie and Caspian gull visits to the islets, we applied GLMM with logit link function considering nest survival as binary response variable (1: nest survived and eggs hatched; 0: nest predated) and magpie and Caspian gull visits to islets, islet size, islet distance from the shore and islet vegetation height as explanatory variables. Separate models 
were built for each species or species group of native waterbirds. Magpie visits were considered as a categorical explanatory variable; islets where magpies were observed at least once were coded as 1 and islets where magpies were not noted were coded as 0 . In the case of Caspian gull, the islets were classified in three categories as described for the first GLMM (see above). The year of the study and the identity of the islet were assigned as random factors. In the case of ducks, grebes and rails, species constituted another random variable, since the low number of pairs of particular species within these groups precluded a complex, species-level analysis. Data on carrion crow visitation were excluded because of the small sample size; we analyzed pooled data on visitation rates by both magpie and carrion crow, but the results were very similar to those obtained in the analysis based solely on the magpie data.

At the control reservoir, we calculated temporal trends in the number of pairs for each particular species or group, as well as for the entire waterbird community. To compare the factors affecting nesting success probability at this reservoir, we also built a GLMM as described above for the entire community and for the black-headed gull. This was because the number of breeding pairs in most species was much lower than for the reservoir colonized by Caspian gull and, with the exception of black-headed gulls, did not allow a reasonable, specieslevel, statistical analysis to be made. Caspian gull visitations on the islets were not included in this model, as we never observed this species at this reservoir. The GLMM with logit link was also used to compare nesting success of different species and species groups breeding on islets located close to the shore (within $50 \mathrm{~m}$ from the shoreline) and on islets in central part of the invaded reservoir.

Finally, we built a GLMM with logit link function to compare the overall nesting success probability between the invaded and control reservoir. The dependent variable was nesting success expressed as in former GLMMs and the explanatory variable was reservoir type (invaded and control). In this model we included species, year and islet identity as random effects. Because islet identity was specific to reservoir type, and because the study was carried out, to some extent, in different years at two reservoirs, the islet identity and year were nested in reservoir type. This analysis was also repeated excluding nests located at the shore, to see if general differences in nesting success probability between two reservoirs were affected by nests located near shore.

All estimates of function slopes (betas) and means are given with standard errors and the significance level was set at $\alpha=0.05$

\section{Results}

Native predator community

The magpie was the most common native predator breeding on the shore of the reservoir invaded by Caspian gulls (Fig. 2). One pair of carrion crow Corvus corone corinx also nested on the shore of the reservoir and one or two fox dens were present there each year.

Magpies visited islets near the shores much more frequently than islets in the central part of the invaded reservoir (Fig. 2). The probability of magpies being noted on islets was negatively related to the distance of the islets from the shoreline $(\beta=-0.108 \pm 0.024 ; \quad$ GLMM $F_{1,110.5}=12.948 ; \quad P<0.001 ; n=129$ magpie visits observed on 42 islets during the years 1996-2001) but was not linked with either islet size $(\beta=0.027 \pm 0.019$; GLMM $\left.F_{1,121}=2.557 ; P=0.112\right)$ or vegetation height $\left(\beta=-0.008 \pm 0.006\right.$; GLMM $\left.F_{1,120}=1.420 ; P=0.236\right)$. A similar pattern was found for the carrion crow. However, the sample size in this case was much lower; we observed 18 visits and 15 were to islets located within a $50 \mathrm{~m}$ distance of the shoreline (all of these islets but one were also visited by magpies).

Twenty cases of egg predation by magpies were directly observed at the invaded reservoir; 16 on unattended blackheaded gull nests, two on common moorhen nests and two on mallard nests. Two cases of egg predation by carrion crow were also directly observed; one on a black-headed gull nest and one on a tufted duck nest. All but two were observed on islets within $50 \mathrm{~m}$ of the shoreline. All nests built directly on the shores, namely 43 black-headed gull nests, two mallard nests and one common moorhen nest, were depredated by magpie and red fox. We observed two cases of Caspian gull predation on black-headed gull eggs and 14 predation events on black-headed gull chicks. These were predominantly performed by a few pairs from one islet and it is probable that they specialized in this particular manner of food finding.

In the control reservoir the only native predator was the magpie (Fig. 2). Similar to the invaded reservoir, the probability of magpies being observed at a given islet was negatively related to its distance from the shore $(\beta=$ $-0.148 \pm 0.102 ; \quad$ GLMM $\quad F_{1,83}=5.717 ; \quad P=0.019$; $n=67$ magpie visits to 16 islets in the years 1997-2001 and in 2003), but was not linked with either islet size $\left(\beta=0.101 \pm 0.75\right.$; GLMM $\left.F_{1,80}=2.333 ; P=0.130\right)$ or vegetation height $\left(\beta=-0.411 \pm 0.380 ;\right.$ GLMM $F_{1,80.1}=$ 2.091; $P=0.152)$. We observed 31 unsuccessful attempts by magpies to steal black-headed gull eggs from islets located relatively close to the shore of the control reservoir. 
Fig. 2 Number of breeding pairs and flight distances of magpie on islets at the reservoir invaded by Caspian gull (grey bars) and at the control reservoir (black bars). A cross indicates lack of data
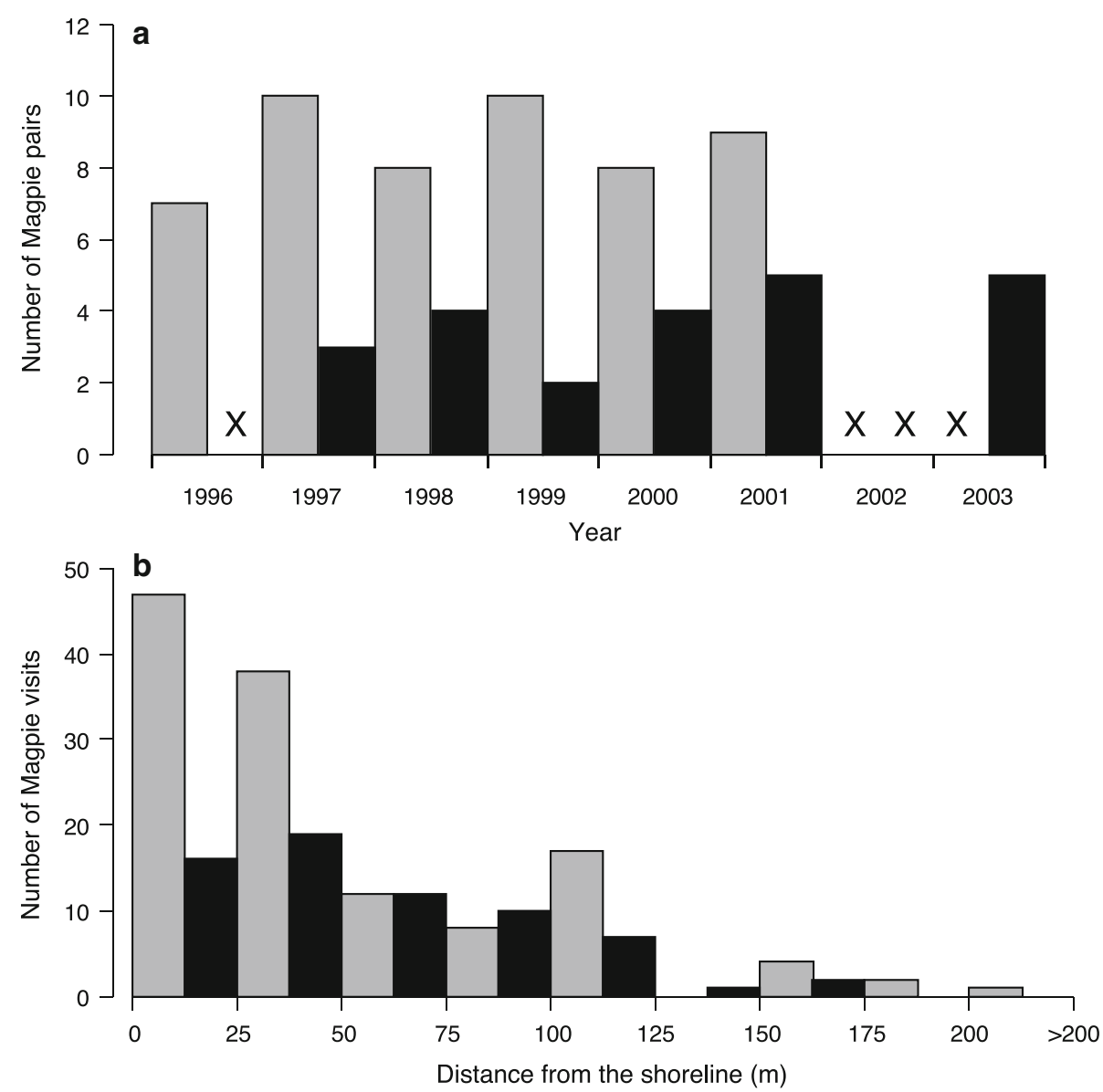

The waterbird community and its response to the invasion by Caspian gull

The numbers of grebes, ducks, rails and common gulls were relatively constant at the invaded reservoir during the study period (Fig. 3) and only the number of breeding black-headed gulls decreased with time [Table 1; Fig. 3, Electronic Supplementary Material (ESM)]. The number of breeding Caspian gulls increased and this species took over most (69 out of 86) of the available islets (Table 1; Fig. 3; ESM). The population sizes of almost all the native waterbirds (with the exception of black-headed gulls) were not statistically correlated with the number of Caspian gulls (Table 1).

In contrast to the population result, the spatial distribution of the nests of all the native waterbirds changed significantly. In all the waterbirds, the number of nests built on islets near the shore, defined as those up to $50 \mathrm{~m}$ from the shoreline, increased significantly with the rising number of Caspian gull, as follows: grebes $r=0.951, P=0.004$; ducks $r=0.934, P=0.006$; rails $r=0.943, \quad P=0.005 ; \quad$ common gull $r=0.935$, $P=0.006$; and black-headed gull $r=0.855, P=0.030$ (Fig. 3; ESM).
At the control reservoir, the number of breeding native waterbirds was stable, apart from the black-headed gull and grebes, which increased in number (Table 1) over the years encompassed by the study, in contrast to the reservoir invaded by Caspian gull. The number of nests located on islets near the shore of the control reservoir was stable over the same period for both ducks ( $r=0.777, P=0.123)$, rails $(r=0.828, P=0.069)$, common gull $(r=0.586$, $P=0.250)$, black-headed gull ( $r=0.437, P=0.384)$ and when all species were pooled in the analysis $(r=0.426$, $P=0.427$; Fig. 3; ESM). No grebe nests were built near or at the shore at this reservoir.

We found no statistically significant differences in the population growth rates of any of the studied species or species groups between the invaded and control reservoirs (Table 2). Overall, the entire bird communities at both reservoirs had growth rates close to one, indicating stable populations.

\section{Determinants of the nesting success}

The probability of nesting success at the invaded reservoir was negatively related to the presence of magpies on islets for ducks and rails (Table 3), but not for grebes, common 

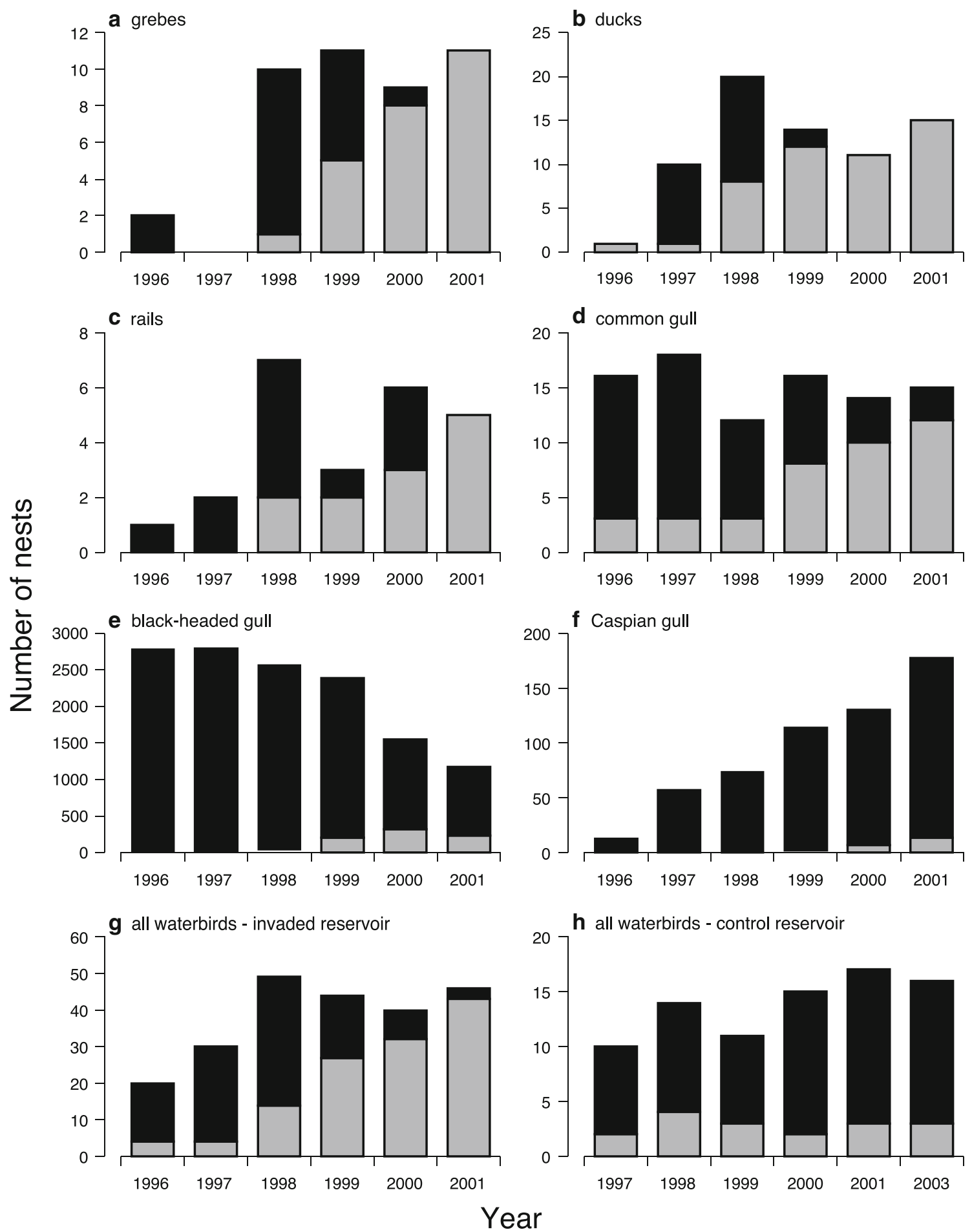

Fig. 3 Changes in the number of nests for a grebes, $\mathbf{b}$ ducks, $\mathbf{c}$ rails, d common gull, e black-headed gull, $\mathbf{f}$ Caspian gull, $\mathbf{g}$ all native breeding waterbirds, excluding black-headed gull at the reservoir invaded by Caspian gull, and $\mathbf{h}$ for all native breeding waterbirds, excluding black-headed gull, at the control reservoir. Black bars indicate the number of nests in the central part of the reservoirs and grey bars show the number of nests within $50 \mathrm{~m}$ of the shoreline. The scales of the vertical axes differ between the panels gull, black-headed gull or Caspian gull (Tables 3, 4). Moreover, it was positively related to the distance from the shore for ducks, rails and black-headed gull (Tables 3, 4;
Fig. 4), but not for grebes, common gull or Caspian gull (Fig. 4). For the black-headed gull, nesting success was also positively related to islet size and vegetation height 
Table 1 Bootstrapped correlation coefficients ( $P$ value in brackets) between the number of breeding pairs of native waterbirds, Caspian gulls, magpies and time (years of study) at the invaded and control reservoirs

\begin{tabular}{|c|c|c|c|c|c|}
\hline & \multicolumn{3}{|c|}{ Invaded reservoir ( $n=6$ years) } & \multicolumn{2}{|c|}{$\begin{array}{l}\text { Control reservoir } \\
(n=6 \text { years })\end{array}$} \\
\hline & $\begin{array}{l}\text { Caspian } \\
\text { gull }\end{array}$ & Magpie & Time & Magpie & Time \\
\hline Grebes & $\begin{array}{l}0.764 \\
\quad(0.090)\end{array}$ & $\begin{array}{l}0.079 \\
(0.866)\end{array}$ & $\begin{array}{l}0.800 \\
\quad(0.081)\end{array}$ & $\begin{array}{l}0.181 \\
\quad(0.744)\end{array}$ & $\begin{array}{l}0.945 \\
\quad(0.017)\end{array}$ \\
\hline Ducks & $\begin{array}{l}0.566 \\
(0.220)\end{array}$ & $\begin{array}{l}0.380 \\
(0.467)\end{array}$ & $\begin{array}{l}0.562 \\
\quad(0.253)\end{array}$ & $\begin{array}{l}0.188 \\
\quad(0.786)\end{array}$ & $\begin{array}{l}0.509 \\
\quad(0.319)\end{array}$ \\
\hline Rails & $\begin{array}{l}0.564 \\
\quad(0.224)\end{array}$ & $\begin{array}{l}0.019 \\
(0.811)\end{array}$ & $\begin{array}{l}0.632 \\
\quad(0.207)\end{array}$ & $\begin{array}{l}0.956 \\
(0.020)\end{array}$ & $\begin{array}{l}0.828 \\
\quad(0.062)\end{array}$ \\
\hline $\begin{array}{l}\text { Common } \\
\text { gull }\end{array}$ & $\begin{array}{l}0.244 \\
\quad(0.676)\end{array}$ & $\begin{array}{l}0.512 \\
\quad(0.341)\end{array}$ & $\begin{array}{l}0.340 \\
(0.558)\end{array}$ & $\begin{array}{l}0.156 \\
\quad(0.901)\end{array}$ & $\begin{array}{l}0.507 \\
\quad(0.349)\end{array}$ \\
\hline $\begin{array}{l}\text { Black- } \\
\text { headed } \\
\text { gull }\end{array}$ & $\begin{array}{r}-0.912 \\
(0.003)\end{array}$ & $\begin{array}{l}0.000 \\
\quad(0.973)\end{array}$ & $\begin{array}{c}-0.949 \\
(<0.001)\end{array}$ & $\begin{array}{l}0.522 \\
\quad(0.308)\end{array}$ & $\begin{array}{l}\mathbf{0 . 8 4 6} \\
\quad(0.015)\end{array}$ \\
\hline $\begin{array}{l}\text { Caspian } \\
\text { gull }\end{array}$ & $\mathrm{n} / \mathrm{a}$ & $\begin{array}{l}0.369 \\
(0.508)\end{array}$ & $\begin{array}{l}0.990 \\
\quad(<0.001)\end{array}$ & $\mathrm{n} / \mathrm{a}$ & $\mathrm{n} / \mathrm{a}$ \\
\hline Magpie & $\begin{array}{l}0.369 \\
\quad(0.506)\end{array}$ & $\mathrm{n} / \mathrm{a}$ & $\begin{array}{l}0.265 \\
\quad(0.671)\end{array}$ & $\mathrm{n} / \mathrm{a}$ & $\begin{array}{l}0.686 \\
\quad(0.117)\end{array}$ \\
\hline
\end{tabular}

Statistically significant correlations are shown in bold. Caspian gulls were not included for the control reservoir because this species was not recorded there

$n / a$ not applicable

(Table 4). For all species, neither the presence of breeding Caspian gulls nor their visits to islets had any statistically significant effects on nesting success probability (Tables 3, 4).

At the control reservoir, none of the variables investigated had a statistically significant effect on nesting success

Overall, the nesting success probability was slightly lower at the invaded reservoir $[0.58 ; 95 \%$ CI $(0.42,0.72)]$ than at the control one $[0.69 ; 95 \%$ CI $(0.53,0.82)$, GLMM $F_{1,345}=4.365, P=0.037, n=347$ nests]. This difference was also significant when only nests of black-headed gull were analyzed (GLMM $F_{1,144}=4.169, \quad P=0.043$, $n=146$ nests) with success probability of 0.55 [95\% CI $(0.46,0.65)]$ and 0.74 [95 \% CI $(0.57,0.86)]$ at the invaded and control reservoirs, respectively. However, when we removed nests located close to shore from these analyses, it was apparent that the general nesting success of waterbirds at the invaded reservoir $[0.75 ; 95 \% \mathrm{CI}(0.66,0.82)]$ and at the control one $[0.82 ; 95 \% \mathrm{CI}(0.72,0.90)]$ was similar (GLMM $F_{1,197}=0.030, P=0.863, n=199$ nests). The same analysis performed for black-headed gull also resulted in non-significant differences in nesting success at the invaded reservoir $[0.88 ; 95 \% \mathrm{CI}(0.75,0.99)]$ and at the control one $[0.85 ; 95 \%$ CI $(0.70,0.98)$; GLMM $F_{1,81}=1.344, P=0.250, n=83$ nests].
Table 2 Mean (SEM) rate of population growth of native waterbirds, Caspian gulls and magpies at the invaded and control reservoirs

\begin{tabular}{|c|c|c|c|c|}
\hline & \multicolumn{2}{|c|}{ Growth rate } & \multirow{2}{*}{$\begin{array}{l}\text { Bootstrapped } \\
t\end{array}$} & \multirow[t]{2}{*}{$P$} \\
\hline & $\begin{array}{l}\text { Invaded } \\
\text { reservoir }\end{array}$ & $\begin{array}{l}\text { Control } \\
\text { reservoir }\end{array}$ & & \\
\hline Grebes & $\begin{array}{l}0.781 \\
\quad(0.275)\end{array}$ & $\begin{array}{l}1.500 \\
(0.500)\end{array}$ & -1.252 & 0.359 \\
\hline Ducks & $\begin{array}{l}2.970 \\
\quad(1.773)\end{array}$ & $\begin{array}{l}1.076 \\
(0.129)\end{array}$ & 1.065 & 0.386 \\
\hline Rails & $\begin{array}{l}1.752 \\
(0.537)\end{array}$ & $\begin{array}{l}1.400 \\
(0.291)\end{array}$ & 0.576 & 0.571 \\
\hline Common gull & $\begin{array}{l}1.014 \\
(0.113)\end{array}$ & $\begin{array}{l}1.004 \\
(0.149)\end{array}$ & 0.053 & 0.951 \\
\hline Black-headed gull & $\begin{array}{l}0.853 \\
\quad(0.065)\end{array}$ & $\begin{array}{l}3.080 \\
\quad(1.605)\end{array}$ & -1.610 & 0.113 \\
\hline Caspian gull & $\begin{array}{l}1.946 \\
(0.613)\end{array}$ & $\mathrm{n} / \mathrm{a}$ & $\mathrm{n} / \mathrm{a}$ & $\mathrm{n} / \mathrm{a}$ \\
\hline Magpie & $\begin{array}{l}1.081 \\
(0.124)\end{array}$ & $\begin{array}{l}1.217 \\
(0.244)\end{array}$ & 1.081 & 0.637 \\
\hline $\begin{array}{l}\text { Native waterbirds } \\
\text { total }^{\text {a }}\end{array}$ & $\begin{array}{l}1.218 \\
(0.151)\end{array}$ & $\begin{array}{l}1.117 \\
(0.100)\end{array}$ & 0.560 & 0.577 \\
\hline $\begin{array}{l}\text { Native waterbirds } \\
\text { total }^{\text {b }}\end{array}$ & $\begin{array}{l}0.857 \\
(0.064)\end{array}$ & $\begin{array}{l}2.666 \\
(0.982)\end{array}$ & -1.911 & 0.065 \\
\hline
\end{tabular}

Caspian gulls were not included for the control reservoir because this species was not recorded there

$n / a$ not applicable

a Black-headed gull excluded

b Black-headed gull included

\section{Discussion}

Our results indicate that interactions between native predators and prey may by altered by the invasion of alien species. As predicted, native opportunistic corvids visited mostly islets located close to shore (Table 5). According to expectations, when the population of invasive Caspian gulls grew the native waterbirds were outcompeted from their preferred breeding islets by this species and forced to breed on suboptimal islets close to shore (Table 5). This resulted in increased egg predation by native predators that visited islets near shore. We may call this a top-down-top effect as the potential invasive predator affected species from lower trophic levels via facilitation of native predators. Contrary to expectations (Table 5), the effect of Caspian gulls on spatial changes in the nest distribution of native waterbirds did not correspond with their population sizes as these were stable in most of species. Thus, the invasion of Caspian gulls has cascading, multilevel effects on the native species and structure of their assemblages. As far as we know, these are the first such effects to be found in a multi-predator community that included an invasive predator, with shifts in the distribution of native waterbirds 


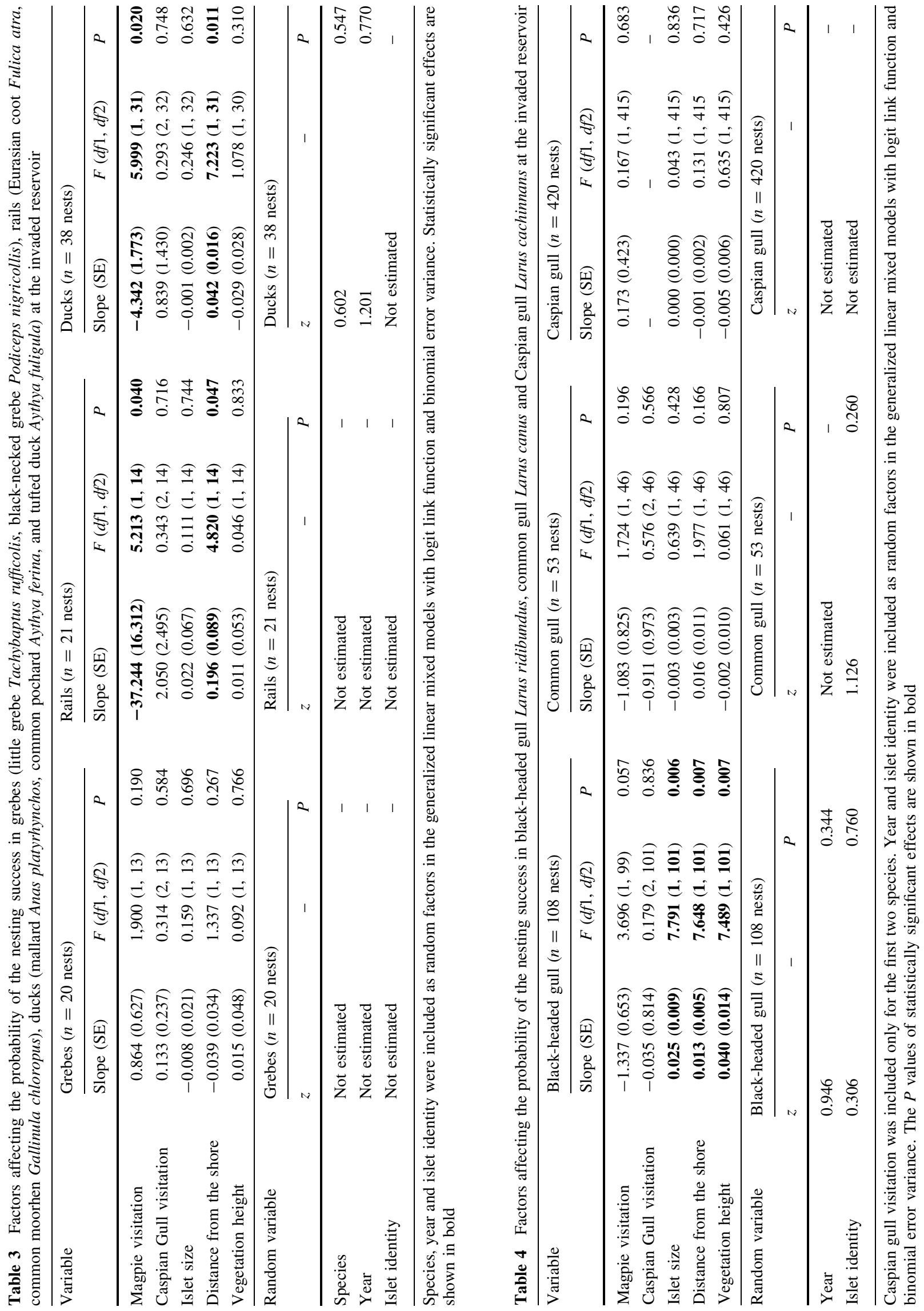


Fig. 4 The nesting success probability (whiskers indicate $95 \%$ confidence intervals) of nests located in the central part of the invaded reservoir and near the shore; a grebes, b ducks, c rails, $\mathbf{d}$ common gull, e black-headed gull and f Caspian gull. Number of nests investigated is given in brackets. $* P<0.05$, $* * P<0.01$
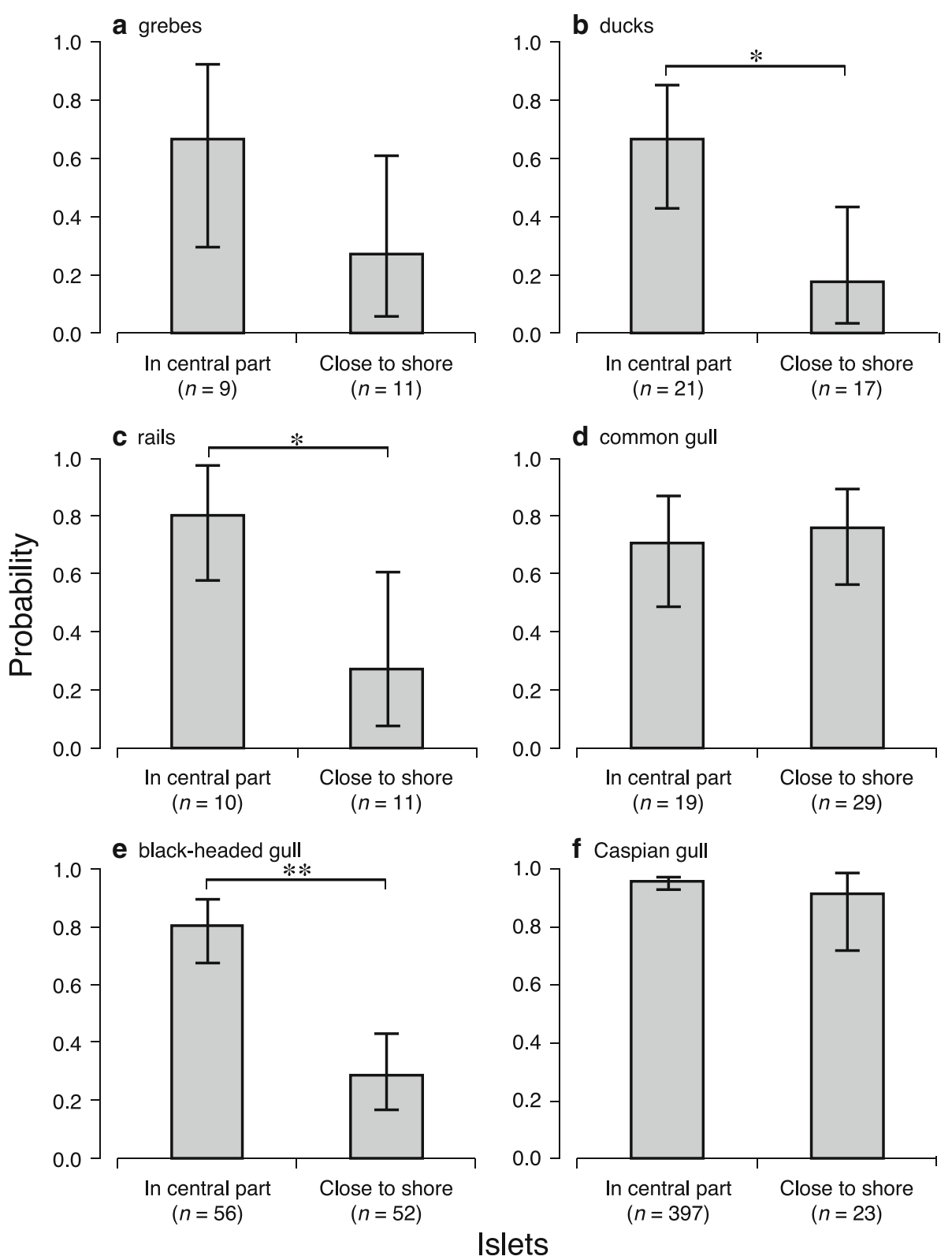

occurring on such a small scale and without substantial changes in population sizes at the community level.

Predation and competition are major processes shaping species communities (Cresswell 2010). The Caspian gull is much larger than the native waterbirds and may predate on their broods and outcompete native species from breeding islets. However, contrary to our expectations, the number of breeding pairs of most native species was stable during the population increase of Caspian gull at the habitat patch scale. This is an important result, indicating that the detrimental impact of this invasive species may be invisible or that there may possibly be a time lag between the invasive gull's colonization of the habitat patch and any corresponding decrease in the population size of native species. This may partially explain the reported lack of effect of large gulls on other waterbirds (Oro and Martinez-Abrain 2007). It also suggests that the expansion of large gulls creates an invasion debt caused by the spatial shift in the distribution of native waterbird nests, with a decrease in population size for most of them probably occurring several years after the invasion event.

It is generally believed that the activity of native predators may limit the effect of invaders (Cresswell 2010). Juliano et al. (2010) showed that native predators reduced the population of invasive species and enabled native prey to survive. In the absence of native predators, the invasive competitor, being much stronger than the native prey, excluded the latter from the habitat. Invasion success is however, dependent on the body size of the invader in comparison to the native predators (Schröder et al. 2009). 
Table 5 Summary of major results and support for hypotheses

\begin{tabular}{|c|c|c|}
\hline Hypothesis & Support & Comments \\
\hline $\begin{array}{l}\text { (1) Native predators, } \\
\text { namely magpies, operate } \\
\text { mostly on islets close to } \\
\text { shore }\end{array}$ & Yes & $\begin{array}{l}\text { Most observations were } \\
\text { within } 50 \mathrm{~m} \text { from the } \\
\text { shoreline }\end{array}$ \\
\hline $\begin{array}{l}\text { (2) Invasion of Caspian gull } \\
\text { leads to a decrease in } \\
\text { population of native } \\
\text { waterbirds }\end{array}$ & $\mathrm{No} / \mathrm{Yes}$ & $\begin{array}{l}\text { The only native species that } \\
\text { decreased after the } \\
\text { invasion was black- } \\
\text { headed gull }\end{array}$ \\
\hline $\begin{array}{l}\text { (3) Because of its large } \\
\text { body size, the Caspian } \\
\text { gull is a stronger } \\
\text { competitor for nesting } \\
\text { sites than native } \\
\text { waterbirds and displaces } \\
\text { them to suboptimal islets } \\
\text { near the shore }\end{array}$ & Yes & $\begin{array}{l}\text { The displacement was not } \\
\text { reflected in changes in the } \\
\text { population size of most } \\
\text { native waterbirds }\end{array}$ \\
\hline $\begin{array}{l}\text { (4) Increasing population of } \\
\text { Caspian gull leads to } \\
\text { increased nest predation } \\
\text { on native waterbirds and } \\
\text { their nesting success at the } \\
\text { invaded reservoir than at } \\
\text { the control reservoir }\end{array}$ & $\mathrm{No} / \mathrm{Yes}$ & $\begin{array}{l}\text { Predation by Caspian gull } \\
\text { rarely observed, possibly } \\
\text { higher during chick } \\
\text { rearing stage. Nesting } \\
\text { success dependent more } \\
\text { on the activity of native } \\
\text { magpie }\end{array}$ \\
\hline $\begin{array}{l}\text { (5) Invasion of Caspian gull } \\
\text { leads to a decline in the } \\
\text { population of native } \\
\text { corvids, as an effect of } \\
\text { scramble competition for } \\
\text { food (eggs of native } \\
\text { waterbirds) }\end{array}$ & No & $\begin{array}{l}\text { Caspian gulls facilitate } \\
\text { native predators by } \\
\text { forcing native waterbirds } \\
\text { to breed near the shores of } \\
\text { reservoirs }\end{array}$ \\
\hline
\end{tabular}

The Caspian gull is much larger than the native predators and the latter were less likely to affect the invader population. Thus, consistent with our hypothesis, the invasive gulls displaced native waterbirds to lower quality islets near the shore, with a high probability of nest predation by native predators. Why did the native waterbirds not disperse and seek suitable nesting sites on other reservoirs? It has been well documented that, following the occupation of sub-optimal habitats, competition for nesting habitat may increase dispersal (Cairns 1992; Blokpoel et al. 1997; Anderson and Devlin 1999). However, dispersal and the search for new suitable breeding sites carries costs. These costs may be energy-related (Riegert et al. 2007), linked to the uncertainty of finding suitable patches (Danchin and Cam 2002; Heinz and Strand 2006) and the inability to predict breeding success in new habitat patches (Doligez et al. 1999). Moreover, many waterbirds are characterized by a high natal breeding site-tenacity (Stenhouse and Robertson 2005; Ibarguchi et al. 2011). However, with regard to our study, an unknown factor is whether the lower nesting success on the islets of the reservoir invaded by the Caspian gull is lower or higher than at other reservoirs in the region. If it was higher, then this could be an explanation as to why the population sizes of most breeding waterbirds were stable over the years encompassed by the study. In our study system, the overall breeding success was lower at the invaded reservoir than in the control one and this was attributable to higher predation on nests built on islets near the shore. This may also explain the population increase of the black-headed gull at the control reservoir where breeding pairs could have moved from the invaded reservoir. Moreover, native waterbirds may be attracted to gull colonies quite simply by the lower probability of nest predation when numerous neighbours are present at the breeding ground (Kruuk 1964; Fuchs 1977; Becker 1995). This may explain, for example, the slight increase in the number of breeding ducks and grebes when the Caspian gull colony developed, as these species are known for the positive association with gull colonies (see below). This also suggests that colonies of Caspian gulls may act as a local sinks for populations of native waterbirds that once attracted to gull colonies may be forced to breed in suboptimal habitats. The long-term consequences of Caspian gull colonies on the reproductive success and persistence of native waterbird populations requires further study.

During the development of the invasive gull population, the role of native predators in nest predation increased. Magpies were a major predator of eggs and benefited from the gull invasion but their behaviour was relatively similar between the invaded and control reservoirs. Magpies are poor fliers, so when flying and approaching islets they are easily detectable and chased away by colonial waterbirds. This may explain why visits of this species to islets located in central parts of two reservoirs were rare. However, when nests of waterbirds are located close to shore, magpies may enter islets relatively inconspicuously and take eggs.

Interestingly, not all waterbird species were equally affected by the population growth of the Caspian gull and subsequent corvid predation. The common gulls and grebes maintained their nesting success independent of the islet's size, its distance from the shore, vegetation height and predator visitation. The common gull is a very aggressive species that chases away all corvids and larger gulls entering its nesting territory. Even a single pair is very successful in seeing off a flock of several magpies or jackdaws Corvus mondedula (P. Skórka, unpublished data). Grebes, on the other hand, cover their eggs with vegetation, making them less conspicuous. The little grebes and blacknecked grebes built their nests in dense vegetation on the islets and probably benefited from the protection afforded by the presence of the gull colony (Burger 1984b).

It is very interesting that the Caspian gull did not intensively depredate the broods of the native waterbirds. This contrasts with the data from other related, large gulls, 
especially the closely related yellow-legged gull Larus (cachinnans) michahellis. In the Mediterranean, this species is an important predator on the eggs and chicks of many seabirds, some of them endangered (Vidal et al. 1998; Rusticali et al. 1999; Hernandez-Matias and Ruiz 2003; Oro et al. 2005). It is also a very strong rival and competes successfully with other, smaller seabirds for breeding sites (Oro et al. 2009), which is in agreement with our results. At the reservoir under study, numerous fish were found at nests of Caspian gulls, indicating that this was a major food for them. Skórka and Wójcik (2008) clearly showed that this species foraged mostly on fish farms and hunted for fish, while the proximity of fish farms is one of the major factors affecting its successful colonization of inland reservoirs (Lenda et al. 2010). Therefore, it is possible that the availability of alternative food resources in the form of the fish, bred in Poland's numerous fish farms, may be a factor that limits the direct predatory impact of this invasive gull on native waterbirds. We may not also exclude possibility that Caspian gull predation is stronger on chicks, a phenomenon which was not considered in this study. Some species (for example, grebes, rails and ducks) conceal their nests in high vegetation which may prevent gull predation during egg incubation. However, once hatched, chicks of most waterbirds leave their nests, are mobile and, thus, possibly more exposed to predatory activity of gulls. In our study, however, it was hard to study predation on chicks as they changed location and often hided in dense vegetation that made discrimination between predation and detection failure unfeasible.

Our data on the effects of Caspian gull and native corvids on native waterbirds have some limitations that should be taken into account when generalizing to other areas and species. We had only one invaded and one control reservoir. Having replicates within the reservoir types would be desirable. However, a sampling design of that nature was unattainable for objective reasons, since, despite efforts in the field, it proved impossible to find other reservoirs suitable for our study. In most cases, invasion of a species is an unpredictable process (Lenda et al. 2012) and in the late 1990s the invasion of Caspian gulls had just started. The colony in Tarnów was one of the largest at that time and one of the few in Poland (Skórka et al. 2005; Lenda et al. 2010). Other colonies were also much smaller (Lenda et al. 2010). Therefore, instead, we decided to control for habitat patch structure and nest site availability by choosing reservoirs located close together and in similar landscape. Such an approach made it possible to focus on the main objective of the study, which was a comparison of activity of native corvids, temporal trends in population, nest distribution and nest success of waterbirds between invaded and control reservoirs. The effects we observed in our study are likely to occur in most of wetlands invaded by Caspian gulls in Central Europe because this species invades waterbodies that are inhabited by an already large number of native waterbird species breeding on islets (M. Lenda, unpublished data). Many waterbodies have several islets distributed in different parts and if invaded by Caspian gull, spatial shifts in distribution of nests of native waterbirds are very probable. Wetlands are also important habitat for carrion crow and magpies. Because our analyses encompass several native waterbird species we believe that our results may provide important insight into understanding the interactions between native predators, invasive predators, and potential native prey.

\section{Concluding remarks}

The invasion of Caspian gulls has cascading, multilevel effects on native species populations and the structure of their communities. However, population sizes of all native species but one remained unchanged, suggesting that the effect of invasive species may not be reflected in changes in population sizes of native species. The effects of invasion become much more pronounced when spatial context of nest distribution of native species within a habitat patch and their reproductive output are taken into account. Some native species had low nest survival that was driven by increased predation by native predators. This increased predation was in turn caused by competitive exclusion of native species by Caspian gulls to suboptimal habitats exposed to predation. Therefore, an invasive predator facilitated native predators. Our results imply that the expansion of invasive species can alter the complexity of interactions in waterbird communities. Predicting these changes and their population consequences is of vital importance to more fully understanding the impacts of invasive predators.

Acknowledgments We thank two anonymous referees for their helpful critical comments on the manuscript. This study was funded in partial by the Polish Ministry of Science and Higher Education under Project No. IP 2011 029671. ML was a beneficiary of the Grant for Young Scientists "Start" of the Foundation for Polish Science.

Open Access This article is distributed under the terms of the Creative Commons Attribution License which permits any use, distribution, and reproduction in any medium, provided the original author(s) and the source are credited.

\section{References}

Abrams P (1983) The theory of limiting similarity. Ann Rev Ecol Syst 14:359-376 
Abrams PA (2000) The evolution of predator-prey interactions: theory and evidence. Ann Rev Ecol Syst 31:79-105

Amat JA (1985) Influence of nesting habitat selection on Mallard (Anas platyrhynchos) nesting success. J Ornithol 126:99-101

Anderson JGT, Devlin CM (1999) Restoration of a multi-species seabird colony. Biol Conserv 90:175-181

Becker PH (1995) Effects of coloniality on gull predation on common Tern (Sterna hirundo) chicks. Col Waterbirds 18:11-22

Blokpoel H, Tessier GD, Andress RA (1997) Successful restoration of the island common tern colony requires on-going control of ringbilled gulls. Col Waterbirds 20:98-101

Bompard A, Jaworski CC, Bearez P, Desneux N (2013) Sharing a predator: can an invasive alien pest affect the predation on a local pest? Popul Ecol 55:433-440

Bonnaud E, Bourgeois K, Vidal E, Legrand J, Le Corre M (2009) How can the Yelkouan shearwater survive feral cat predation? A meta-population structure as a solution? Popul Ecol 51:261-270

Bosch M, Oro D, Cantos FJ, Zabala M (2000) Short-term effects of culling on the ecology and population dynamics of the yellowlegged gull. J Appl Ecol 37:369-385

Brzeziński M, Natorff M, Zalewski A, Żmihorski M (2012) Numerical and behavioural responses of waterfowl to the invasive American mink: a conservation paradox. Biol Conserv 147:68-78

Bukaciński D, Bukacińska M (2000) The impact of mass outbreaks of black flies (Simuliidae) on the parental behaviour and breeding output of colonial common gulls (Larus canus). Ann Zool Fennici 37:43-49

Burger J (1984a) Pattern, mechanism, and adaptive significance of territoriality in Herring Gulls (Larus argentatus). Ornithol Monographs 34. A.O.U, Washington DC

Burger J (1984b) Grebes nesting in gull colonies: protective associations and early warning. Am Nat 123:327-337

Cairns DK (1992) Population regulation of seabird colonies. Curr Ornithol 9:37-61

Cresswell W (2010) Predation in bird populations. J Ornithol 152:S251-S263

Crowe O, Austin GE, Colhoun K, Cranswick PA, Kershaw M, Musgrove AJ (2008) Estimates and trends of waterbird numbers wintering in Ireland, 1994/95 to 2003/04. Bird Study 55:66-77

Cupples JB, Crowther MS, Story G, Lethic M (2011) Dietary overlap and prey selectivity among sympatric carnivores: could dingoes suppress foxes through competition for prey? J Mamm 92:590-600

Danchin E, Cam E (2002) Can non-breeding be a cost of breeding dispersal? Behav Ecol Sociobiol 51:153-163

Delany S, Nagy S, Davidson N (2010) State of the world's waterbirds 2010. Wetlands International, Wageningen

Doligez B, Danchin E, Clobert J, Gustafsson L (1999) The use of conspecific reproductive success for breeding habitat selection in a non-colonial, hole nesting species, the collared flycatcher. J Anim Ecol 68:1193-1206

Elliott GP, Wilson PR, Taylor RH, Beggs JR (2010) Declines in common, widespread native birds in a mature temperate forest. Biol Conserv 143:2119-2126

Ellis JC, Shulman MJ, Jessop H, Suomala R, Morris S, Seng V, Wagner M, Mach K (2007) Impact of raccoons on breeding success in large colonies of great black-backed gulls, and herring gulls. Waterbirds 30:375-383

Erwin RM, Truitt BR, Jimenez JE (2001) Ground-nesting waterbirds and mammalian carnivores in the Virginia barrier island region: running out of options. J Coast Res 17:292-296

Evans EW, Toler TR (2007) Aggregation of polyphagous predators in response to multiply prey: ladybirds (Coleoptera: Coccinellidae) foraging in alfalfa. Popul Ecol 49:29-36

Ewins PJ (1991) Egg predation by corvids in gull colonies on Lake Huron. Col Waterbirds 14:186-189
Faber M, Betleja J, Gwiazda R, Malczyk P (2001) Mixed colonies of large white-headed gulls in southern Poland. British Birds 94:529-534

Farrer EC, Goldberg DE (2009) Litter drives ecosystem and plant community changes in cattail invasion. Ecol Appl 19:398-412

Fasola M, Goutner V, Walmsley J (1993) Comparative breeding biology of the gulls and terns in the four main deltas of the northern Mediterranean. In: Aguilar JS, Monbailliu X, Paterson AM (eds) Estatus y conservacio'n de aves marinas. Sociedad Espanola de Ornitologia, Madrid, pp 99-111

Filchagov AV (1996) Colonisation of the central part of the EastEuropean plain by Larus argentatus-cachinnans-fuscus gull: geography, parentage of colonists and perspectives. Ibis 138:148-149

Finke DL, Snyder WE (2010) Conserving the benefits of predator biodiversity. Biol Conserv 143:2260-2269

Finlayson CM, Davidson NC (1999) Global review of wetland resources and priorities for wetland inventory. Ramsar Bureau Contract 56. Ramsar Convention Bureau, Gland

Finney SK, Harris MP, Keller LF, Elston DA, Monaghan P, Wanless S (2003) Reducing the density of breeding gulls influence the pattern of recruitment of immature Atlantic puffins Fratercula arctica to a breeding colony. J Appl Ecol 40:545-552

Flachaire E (1999) A better way to bootstrap pairs. Econ Lett 64:257-262

Flanders AA, Kuvlesky WP, Rythven DC, Zaiglin RE, Bingham RL, Fulbright TE, Hernandez F, Brennan LA (2006) Effects of invasive exotic grasses on South Texas rangeland breeding birds. Auk 123:171-182

Forstmeier W, Weiss I (2004) Adaptive plasticity in nest-site selection in response to changing predation risk. Oikos 104:487-499

Fuchs E (1977) Predation and anti-predator behaviour in a mixed colony of terns Sterna sp. and black-headed gulls Larus ridibundus with special reference to the sandwich tern Sterna sandvicensis. Ornis Scand 8:17-32

Gregory GJ, Quijón PA (2011) The impact of a coastal invasive predator on infaunal communities: assessing the roles of density and a native counterpart. J Sea Res 66:181-186

Gwiazda R (2004) Fish in the diet of the cormorant and yellow-legged gull breeding near ponds (upper Vistula river valley, southern Poland): preliminary study. Acta Zool Cracov 47:17-26

Hardin G (1960) The competitive exclusion principle. Science 131:1292-1297

Heinz SK, Strand E (2006) Adaptive patch searching strategies in fragmented landscapes. Evol Ecol 20:113-130

Hernandez-Matias A, Ruiz X (2003) Predation on common tern eggs by the yellow-legged gull at the Ebro Delta. Sci Mar 67:S95S101

Hogg BN, Daane KM (2011) Diversity and invasion within a predator community: impacts on herbivore suppression. J Appl Ecol 48:453-461

Hollebone A, Hay M (2008) An invasive crab alters interaction webs in a marine community. Biol Inv 10:347-358

Ibarguchi G, Gaston AJ, Friesen VL (2011) Philopatry, morphological divergence, and kin groups: structuring in thick-billed murres Uria lomvia within a colony in Arctic Canada. J Avian Biol 42:134-150

IBM Corp Released (2011) IBM SPSS statistics for windows, version 20.0. IBM Corp., Armonk

Jadwiszczak P (2009) Rundom Pro 3.14. Software for classical and computer-intensive statistics available free from the New Rundom Site (http://pjadw.tripod.com)

Jonart LM, Hill GE, Badyaev AV (2007) Fighting ability and motivation: determinants of dominance and contest strategies in females of passerine bird. Anim Behav 74:1675-1681 
Jonsson L (1998) Yellow-legged gulls and yellow-legged herring gulls in the Baltic. Alula 4:74-100

Juliano SA, Lounibos LP, Nishimura N, Greene K (2010) Your worst enemy could be your best friend: predator contributions to invasion resistance and persistence of natives. Oecologia 162:709-718

Kajzer J, Lenda M, Kosmicki A, Bobrek R, Kowalczyk T, Martyka R, Skórka P (2012) Patch occupancy and abundance of local populations in landscapes differing in degree of habitat fragmentation: a case study of the colonial black-headed gull, Chroicocephalus ridibundus. J Biogeogr 39:371-381

Keddy PA, Fraser LH, Solomeshch AI, Junk WJ, Campbell D, Arroyo TK, Alho CJR (2009) Wet and wonderful: the world's largest wetlands are conservation priorities. Bioscience 59:39-51

Kiesecker JM, Blaustein AR (1997) Population differences in responses of red-legged frogs (Rana aurora) to introduced bullfrogs. Ecology 78:1752-1760

Kruuk H (1964) Predator and anti-predator behaviour of the black headed gull (Larus ridibundus). Behaviour 11:S1-S29

Kuehl AK, Clark WR (2002) Predator activity related to landscape features in northern Iowa. J Wildl Man 66:1224-1234

Lenda M, Zagalska-Neubauer M, Neubauer G, Skórka P (2010) Do invasive species undergo metapopulation dynamics? A case study of the invasive Caspian Gull, Larus cachinnans, in Poland. J Biogeogr 37:1824-1834

Lenda M, Skórka P, Knops JMH, Moroń D, Tworek S, Woyciechowski M (2012) Plant establishment and invasions: an increase in a seed disperser combined with land abandonment causes an invasion of the non-native walnut in Europe. Proc R Soc B 279:1491-1497

Lima SL (2009) Predators and the breeding bird: behavioural and reproductive flexibility under the risk of predation. Biol Rev $84: 485-513$

Lindstrom K (1988) Male-male competition for nest sites in the sand goby, Pomatoschistus minutus. Oikos 53:67-73

Ma ZJ, Wang Y, Gan XJ, Li B, Cai YT, Chen JK (2009) Waterbird population changes in the wetlands at Chongming Dongtan in the Yangtze River estuary, China. Environ Man 43:1187-1200

Malling Olsen K, Larsson H (2004) Gulls of Europe. Christopher Helm, Asia and North America

McGeoch M, Butchart SHM, Spear D, Marais E, Kleynhan EJ, Symes A, Chanson J, Hoffmann M (2010) Global indicators of biological invasion: species numbers, biodiversity impact and policy responses. Divers Distrib 16:95-108

Montevecchi WA (1976) Egg size and the egg predatory behaviour by crows. Behaviour 57:307-320

Montevecchi WA (1977) Predation in a salt marsh laughing gull colony. Auk 94:583-585

Mooney HA, Cleland EE (2001) The evolutionary impact of invasive species. Proc Natl Acad Sci USA 98:5446-5451

Morosinotto C, Thomson RL, Korpimaki E (2010) Habitat selection as an antipredator behaviour in a multi-predator landscape: all enemies are not equal. J Anim Ecol 79:327-333

Nordström M, Högmander J, Laine J, Nummelin J, Laanetu N, Korpimäki E (2002) Variable responses of waterfowl breeding populations to long-term removal of introduced American mink. Ecography 25:385-394

Oro D, Martinez-Abrain A (2007) Deconstructing myths on large gulls and their impact on threatened sympatric waterbirds. Anim Conserv 10:117-126

Oro D, De Leon A, Minguez E, Furness RW (2005) Estimating predation on breeding European Storm-petrels by yellow-legged gulls. J Zool 245:421-429

Oro D, Perez-Rodriguez A, Martinez-Vilalta A, Bertolero A, Vidal F, Genovart M (2009) Interference competition in a threatened seabird community: a paradox for successful conservation. Biol Conserv 142:1830-1835

Paine RT (1966) Food web complexity and species diversity. Am Nat 100:65-75

Paolucci EM, Maclsaac HJ, Ricciardi A (2013) Origin matters: alien consumers inflict greater damage to prey populations than naive consumers. Divers Distrib 19:988-995

Pons P, Bas JM, Estany-Tigerstrom D (2010) Coping with invasive alien species: the Argentine ant and the insectivorous bird assemblage of Mediterranean oak forests. Biodiv Conserv 19:1711-1723

Pope KL, Garwood JM, Welsh HH Jr, Lawler SP (2008) Evidence of indirect impacts of introduced trout on native amphibians via facilitation of a shared predator. Biol Conserv 141:1321-1331

Rahel FJ, Olden JD (2008) Assessing the effects of climate change on aquatic invasive species. Conserv Biol 22:521-533

Rands MRW, Adams WM, Bennun L, Butchart SHM, Clements A, Coomes D, Entwistle A, Hodge I, Kapos V, Scharlemann JPW, Sutherland WJ, Vira B (2010) Biodiversity conservation beyond 2010. Science 329:1298-1303

Relyea RA (2003) How prey respond to combined predators: a review and an empirical test. Ecology 84:1827-1839

Riegert J, Fainova D, Mikes V, Fuchs R (2007) How urban Kestrels Falco tinninculus divide their hunting grounds: partitioning or cohabitation? Acta Ornithol 42:69-76

Ruiz-Olmo J, Blanch F, Vidal F (2003) Relationship between the Red Fox and waterbirds in the Ebro Delta natural park N.E. Spain. Waterbirds 26:217-225

Rusticali R, Scarton F, Valle R (1999) Habitat selection and hatching success of Eurasian Oystercatchers in relation to nesting Yellowlegged Gulls ad human presence. Waterbirds 22:367-375

Salo P, Korpimäki E, Banks PB, Nordstöm M, Dickman CR (2007) Alien predators are more dangerous than native predators to prey populations. Proc R Soc B 274:1237-1243

Sandilyan S, Thiyagesan K, Nagarajan R (2010) Major decline in species-richness of waterbirds in the Pichavaram mangrove wetlands, southern India. Wader Study Group Bull 117:91-98

Schmitz OJ (1998) Direct and indirect effects of predation and predation risk in old-field interaction webs. Am Nat 151:327-342

Schmitz OJ, Beckerman A, O’Brien KM (1997) Behaviourally mediated trophic cascades, effects of predation risk on food web interactions. Ecology 78:1388-1399

Schröder A, Nilsson KA, Persson L, Van Kooten T, Reichstein B (2009) Invasion success depends on invader body size in a sizestructured mixed predation-competition community. J Anim Ecol 78:1152-1162

Skórka P, Wójcik JD (2008) Habitat utilisation, feeding tactics and age related feeding efficiency in the Caspian Gull Larus cachinnans. J Ornithol 149:31-39

Skórka P, Wójcik JD, Martyka R (2005) Colonization and population growth of Yellow legged Gull L. cachinnans in southeastern Poland: causes and influence on native species. Ibis 147:471-482

Skórka P, Martyka R, Wójcik JD, Babiarz T, Skórka J (2006) Habitat and nest site selection in the Common Gull Larus canus in southern Poland: significance of man-made habitats for conservation of an endangered species. Acta Ornithol 41:137-144

Skórka P, Lenda M, Martyka R, Tworek S (2009) The use of optimal foraging and metapopulation theories to predict animal movement and foraging decisions in mobile animals in heterogeneous landscapes. Landsc Ecol 24:599-609

Skórka P, Wójcik JD, Martyka R, Lenda M (2012) Numerical and behavioural response of Black-headed Gull Chroicocephalus ridibundus on population growth of the expansive Caspian Gull L. cachinnans. J Ornithol 153:947-961 
Snyder WE, Evans EW (2006) Ecological effects of invasive arthropod generalist predator. Ann Rev Ecol Evol Syst 37:95-122

Stenhouse IJ, Robertson GJ (2005) Philopatry, site tenacity, mate fidelity, and adult survival in Sabine's Gull. Condor 107:416-423

Stien J, Yoccoz NG, Ims RA (2010) Nest predation in declining population of common eiders Somateria mollisima: an experimental evaluation of the role of hooded crows Corvus cornix. Wildl Biol 16:123-134

Stouffer PC, Caccamise DF (1991) Roosting and diurnal movements of radio-tagged American crows. Wilson Bull 103:387-400

Strubbe D, Matthysen E, Graham CH (2010) Assessing the potential impact of invasive Ring-necked Parakeets Psittacula krameri on native Nuthatches Sitta europaea in Belgium. J Appl Ecol 47:549-557

Sutherland WJ, Alves JA, Amano T, Chang CH, Davidson NC, Finlayson CM, Gill JA, Gill RE, González PM, Gunnarsson TG, Kleijn D, Spray CJ, Székely T, Thompson DBA (2012) A horizon scanning assessment of current and potential future threats facing migratory shorebirds. Ibis 154:663-679

Turner A, Montgomery S (2003) Spatial and temporal scales of predator avoidance, experiments with fish and snails. Ecology 84:616-622
Väänänen V-M (2000) Predation risk associated with nesting in gull colonies by two Aythya species: observations and an experimental tests. J Avian Biol 31:31-35

Vidal E, Medail F, Tatoni T (1998) Is the yellow-legged gull a superabundant bird species in the Mediterranean? Impact on fauna and flora, conservation measures and research priorities. Biodivers Conserv 7:1013-1026

Vitousek PM, Mooney HA, Lubchenco J, Melillo JM (1997) Human domination of Earth's ecosystems. Science 277:494-499

Wilcove DS, Rothstein D, Dubow J, Phillips A, Losos E (1998) Quantifying threats to imperiled species in the US. Bioscience 48:607-615

Wiles GJ, Bart J, Beck RE Jr, Aguon CF (2003) Impacts of the brown tree snake: patterns of decline and species persistence in Guam's avifauna. Conserv Biol 17:1350-1360

Zduniak P (2006) The prey of Hooded Crow (Corvus cornix L.) in wetland: study of damaged egg shells of birds. Pol J Ecol 54:491-498 